\title{
2016 年熊本地震における益城町の建物被害の分析
}

杉野未奈 ${ }^{1)}$ 、山室涼平 ${ }^{2)}$ 、小林素直 ${ }^{3)}$ 、村瀬詩織 ${ }^{4)}$ 、大村早紀 ${ }^{5)}$ 、林康裕 ${ }^{6)}$

1) 正会員 京都大学大学院工学研究科建築学専攻、助教 博士(工学) e-mail : rp-sugino@archi.kyoto-u.ac.jp

2) 学生会員 京都大学大学院工学研究科建築学専攻、修士課程

e-mail : rp-yamamuro@archi.kyoto-u.ac.jp

3) 京都大学大学院工学研究科建築学専攻、博士後期課程 修士(工学)、日本学術振興会特別研究員(DC1) e-mail : rp-kobayashi@archi.kyoto-u.ac.jp

4) 京都大学工学部建築学科、学部生 e-mail : rp-murase@archi.kyoto-u.ac.jp

5) 学生会員 京都大学大学院工学研究科建築学専攻、修士課程 e-mail : rp-ohmura@archi.kyoto-u.ac.jp

6) 正会員 京都大学大学院工学研究科建築学専攻、教授 工博 e-mail : hayashi@archi.kyoto-u.ac.jp

要 約

2016年熊本地震における木造建物の被害の要因を分析することを目的として、益城町で建 物被害が大きかった範囲を対象に空中写真により建物の建築年と倒壊の判定を行った。そ の結果、倒壊被害集中域は帯状であり前震と本震でずれがあることがわかった。また、倒 壊建物と地盤の常時微動計測結果・建築年との関係を分析した。さらに、1981年の新耐震 設計法施行後に建てられた築1982年以降の木造建物でも倒壊した地域があり、倒壊率が最 も高い地域では築1982年以前と以降で倒壊率に大きな差がなかった。

キーワード： 熊本地震、建物被害、倒壊率、建築年、空中写真、GIS

\section{1. はじめに}

2016 年 4 月 14 日から発生した 2016 年熊本地震における一連の地震活動（以下、熊本地震）による甚 大な建物被害が多数報告されている。本論では、 4 月 14 日 21 時 26 分に発生した M6.5 の地震 ${ }^{1)}$ (以下、 前震）および 4 月 16 日 1 時 25 分に発生した M7.3 の地震 ${ }^{1)}$ (以下、本震) の双方で震度 7 を観測し、建 物被害が甚大であった熊本県上益城郡益城町に着目寸る。本論では主に木造建物を対象とし、まず、1981 年の建築基準法施行令改正（以下、新耐震設計法）、2000 年の建築基準法改正に概㸚対応寸るように、 益城町の 1982 年と 2003 年の空中写真を用いて、建物の建築年を判断する。次に、前震および本震後に 撮影された空中写真から、前震および本震によって建物が倒壊したかどうかを判定する。これらの情報 を GIS 上に入力することで、倒壊建物の分布を明らかとする。そして、建物被害の要因を分析するため に、倒壊建物と地盤の常時微動計測結果・建築年との関係を示す。さらに、国や益城町は、全建物のう ち新耐震設計法施行後に建てられた建物や耐震改修・建て替えにより耐震化した建物の割合として算定 
される耐震化率を指標として建物の耐震化の促進を図っている 2,3$)$ こを踏まえ、本論では耐震化率と倒 壊建物との関係についても考察する。

\section{2. 地震と地震動の概要}

図 1 に熊本県の行政区域 4)および益城町の位置を示す。図 2 および図 3 に本論における建物倒壊に対 する検討の対象範囲を示す。対象範囲は、安永、宮園、木山、辻の城、寺迫の 5 地区を含む、益城町の 中でも被害が大きかった範囲とした。同図には、前震および本震時に熊本県の震度計のあった益城町役 場、防災科学技術研究所が運用している強震観測網 KiK-net の地震観測点である KMMH16 の 2 つの地 震観測点の位置を示している。図 2 には、益城町の大字境界 5)、益城町における活断層 ${ }^{6}$ )の位置、熊本 地震の前震および本震の震央 ${ }^{7)}$ の位置も併せて示している。ただし、同図の活断層は文献 6)より熊本地 震以前に公表されたもので推定活断層を含む。同図より、対象範囲は震源および活断層より北側に位置 していることが分かる。図 3 には、対象範囲を東西に横断している県道 28 号線（図中 R28）、県道 28 号線と平行に対象範囲の南の境界を流れている秋津川を併せて示している。同図に示寸本論での対象建 物については 3 章で後述する。

表 1 に地震観測点における NS と EW 方向の最大地動速度 PGV を示す。地動速度は固有周期 20 秒、 減衰定数 $70.7 \% の 1$ 自由度系の応答速度の逆位相として求めており、以降に示す KMMH16の観測記録 は、地表での記録である。同表より、NS 方向に比べて EW 方向の観測記録の PGV が大きいことが分か る。以降、本論では観測記録の $\mathrm{EW}$ 方向に着目して検討を行う。図 4 には、益城町の地震観測点におけ る観測記録 ${ }^{87,9)}$ の $\mathrm{EW}$ 方向について、減衰定数 5\%の擬似速度応答スペクトルを建築基準法の告示によ る工学的基盤でのスペクトルと併せて示す。同図より、両観測点において前震と本震の擬似速度応答ス ペクトルは告示を大きく上回っていることが確認できる。また、表 1 および図 4 より、EW 方向の観測 記録の PGV および擬似速度応答スペクトルは、前震・本震共に KMMH16より益城町役場のほうが大き く、また両観測点において前震より本震のほうが大きかった。

\section{3. 建物倒壊被害データベースの作成}

本論では、建物被害の要因を分析寸るため、道路縁や水域、大字境界、建物の位置や形状、空中写真 から推定した建物の建築年、空中写真から判定した熊本地震により倒壊した建物のデータをGIS上で重 放合わせて地理情報を作成した。表2に本論で用いた地理情報データの一覧を示す。道路縁と水域は2015 年4月1日に更新された国土地理院の基盤地図情報基本項目 ${ }^{10)}$ を、大字境界は2010年10月1日に作成された 政府統計の総合空口の境界データ5)を用いる。

建物形状は、国土地理院の基盤地図情報基本項目 ${ }^{10)}$ を用いる。このデータは、2015年4月1日に作成さ れたもので、各建物の建物形状、建物種別（普通建物、堅ろう建物、普通無壁舎、堅万う無壁舎の4分類）、

ID (建物識別番号) 等が記録されている。本論での対象建物は、建物種別が普通建物に分類され、空中 写真により存在が確認できる建物のみとした。普通建物とは、3階未満の建物および3階以上の木造等で 建築された建物10)のことで、本論での対象建物の多くは木造住宅であると考えられるが、軽量鉄骨造の 建物などが含まれている可能性がある。また、2015年4月1日以降に解体・増設された建物も存在すると 考えられるため、国土地理院とアジア航測による2016年4月15日撮影の空中写真 $\left.{ }^{11)},{ }^{12}\right)$ において建物の変 更が確認できた場合は、GIS上で削除・追加し反映させた。追加した建物についても、空中写真から上 記の定義の普通建物と推定できた建物のみを対象とした。なお、図3および以降の図では、本論の対象建 物および対象範囲内の道路縁のみを示している。

建物建築年のデータは、国土地理院による1982年5月22日および2003年5月1日撮影の空中写真 ${ }^{13)}$ (写真 1、写真2）と前段落で説明した建物形状を用いて作成した。2つの空中写真と建物形状をそれぞれ比較し、 建物の大きさや形から建物の有無を判定することで、建築年が1982年以前、1982年から2003年の間、2003 年以降の建物の3つに分類した。空中写真は、1981年（新耐震設計法）と2000年（建築基準法改正）に近 い撮影年のものを選んでいる。なお、建物の大きさや形から建物の有無を判定しているため、建て替え 


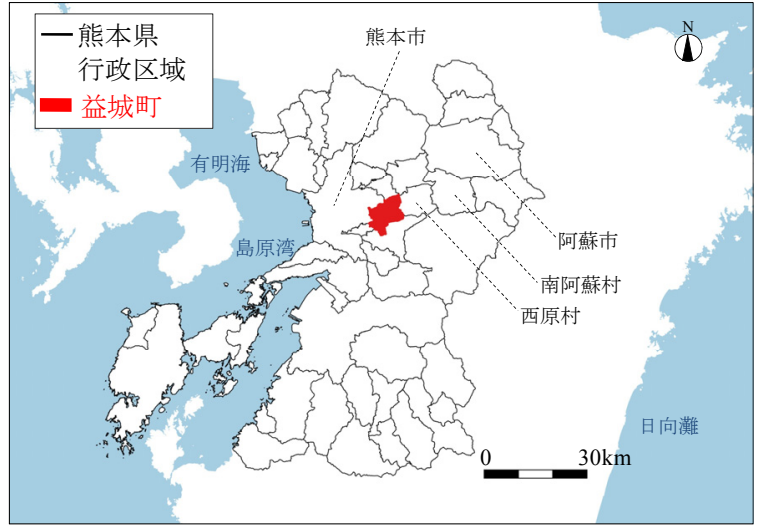

図 1 熊本県上益城郡益城町の位置 ${ }^{4)}$

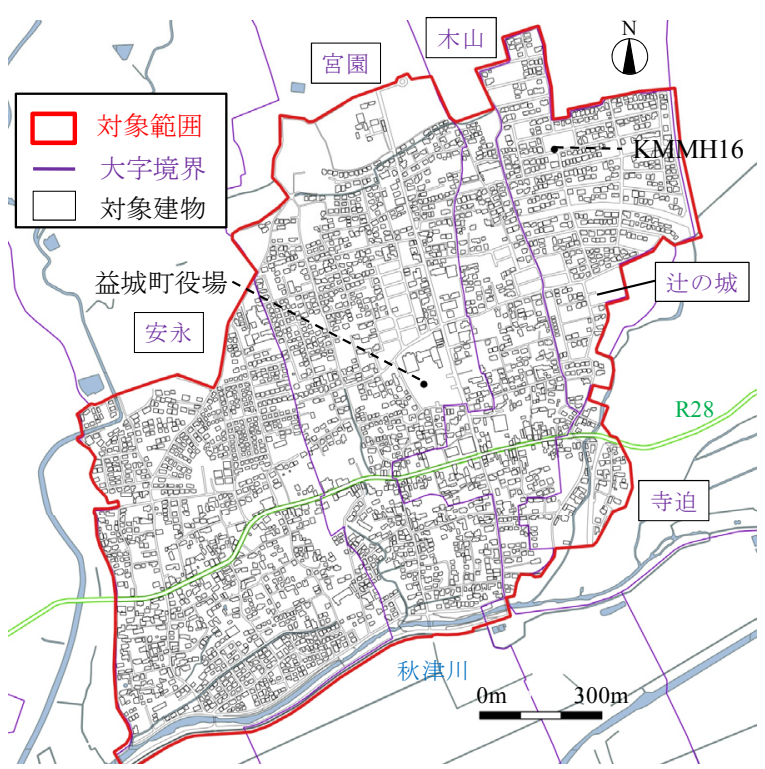

図 3 対象範囲之大字境界 ${ }^{5)}$ 、 対象建物

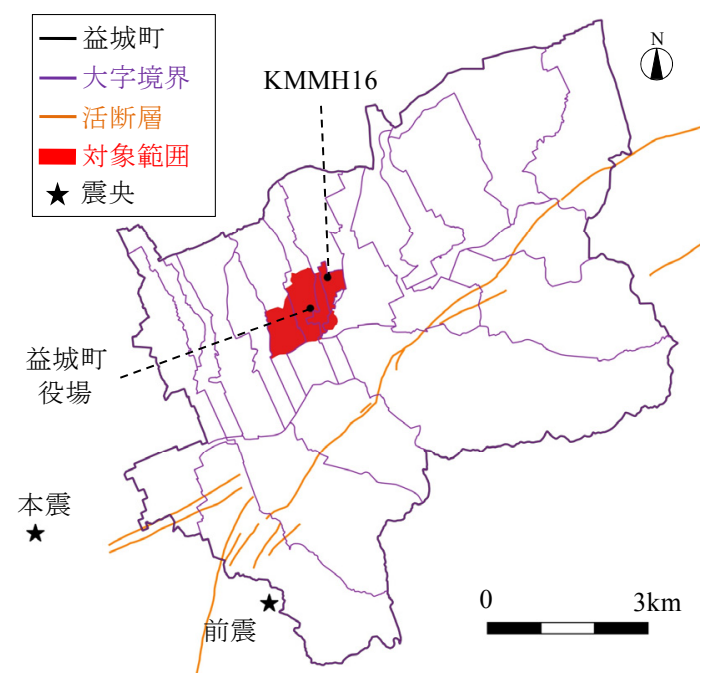

図 2 対象範囲と大字境界 ${ }^{5)}$ 、 活断層 ${ }^{6)}$ 、震央 ${ }^{7)}$ 、地震観測点の位置

表 1 地震観測点の最大地動速度 PGV

\begin{tabular}{|c|c|c|c|c|c|}
\hline \multicolumn{2}{|c|}{} & \multicolumn{2}{|c|}{ 益城町役場 } & \multicolumn{2}{c|}{ KMMH16 } \\
\cline { 3 - 6 } \multicolumn{2}{|c|}{} & 前震 & 本震 & 前震 & 本震 \\
\hline \hline \multirow{2}{*}{$\begin{array}{c}\text { PGV } \\
(\mathrm{cm} / \mathrm{s})\end{array}$} & NS & 117 & 112 & 76 & 77 \\
\cline { 2 - 6 } & EW & 135 & 178 & 92 & 130 \\
\hline
\end{tabular}

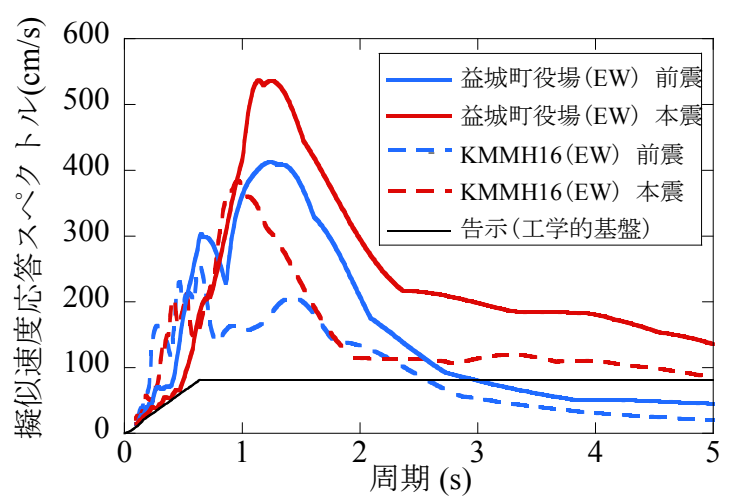

図 4 擬似速度応答スペクトル (減衰定数 $5 \%$ )

などは考慮できていない可能性がある。

熊本地震による建物の倒壊判定は、長谷川ら ${ }^{14)}$ と同様に空中写真を用いて行った。なお、長谷川ら ${ }^{14)}$ は、木造建物について空撮ハイビジョン映像を用いた目視判定で倒壊と判定された建物と、文献 15)に 基づく地上調查で全壊・大破と判定された建物が良い対応関係を示していることを明らかにしている。 本論では、14 日の前震によって倒壊した建物、16 日の本震によって倒壊した建物、非倒壊の建物の 3

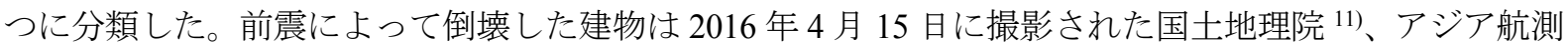
12)による空中写真（例えば写真 3）を用いて判定し、本震によって倒壊した建物は 2016 年 4 月 29 日に 筆者らがドローンを使って撮影した空中写真（例えば写真 4）と国土地理院 ${ }^{16)}$ による空中写真を用いて 判定した。本論では、ある層または複数の層が潰れている建物、あるいは、空中写真でも判読できる程 の顕著な傾斜が確認され、余震で層が潰れる危険性の高い建物を「倒壊」と判定した。倒壊判定は著者 らのうち 4 名で行い、いずれの建物もそのうちの 2 名以上で行った。なお、本論で判定した本震によっ て倒壊した建物には、本震の発生後からドローンでの撮影日までの間に、余震などによって倒壊した建 
表 2 地理情報データー覧

\begin{tabular}{|c|c|c|c|}
\hline & 入力データ & 使用データ & 作成日 \\
\hline \multirow{2}{*}{ 地形 } & 道路縁・水域 & 国土地理院 基盤地図情報基本項目 ${ }^{10)}$ & $2015 / 4 / 1$ \\
\hline & 大字境界 & 政府統計の総合空口 境界データ5) & $2010 / 10 / 1$ \\
\hline \multirow{10}{*}{ 建物 } & \multirow{3}{*}{ 建物形状 } & 国土地理院＼cjkstart基盤地図情報基本項目 ${ }^{10)}$ & $2015 / 4 / 1$ \\
\hline & & 国土地理院 地理院地図（空中写真等） ${ }^{11)}$ & $2016 / 4 / 15$ \\
\hline & & アジア航測＼cjkstart斜め空中写真 ${ }^{12)}$ & $2016 / 4 / 15$ \\
\hline & \multirow{2}{*}{ 建築年 } & 国土地理院 1982年空中写真 ${ }^{13)}$ & $1982 / 5 / 22$ \\
\hline & & 国土地理院 2003年空中写真 ${ }^{13)}$ & $2003 / 5 / 1$ \\
\hline & \multirow{2}{*}{ 倒壊判定（前震） } & 国土地理院 地理院地図（空中写真等） 11) & $2016 / 4 / 15$ \\
\hline & & アジア航測 斜め空中写真 ${ }^{12)}$ & $2016 / 4 / 15$ \\
\hline & \multirow{3}{*}{ 倒壊判定（本震） } & ドローンを用いて撮影した空中写真 & $2016 / 4 / 29$ \\
\hline & & 国土地理院 地理院地図（空中写真等） 16) & $2016 / 4 / 16$ \\
\hline & & 現地調査で撮影した映像（一部地域） & $2016 / 5 / 28-29$ \\
\hline
\end{tabular}

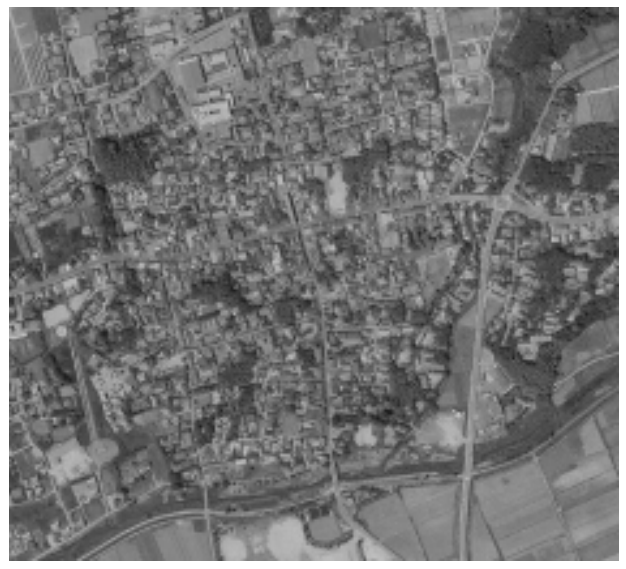

写真1 1982年撮影の空中写真 ${ }^{13)}$

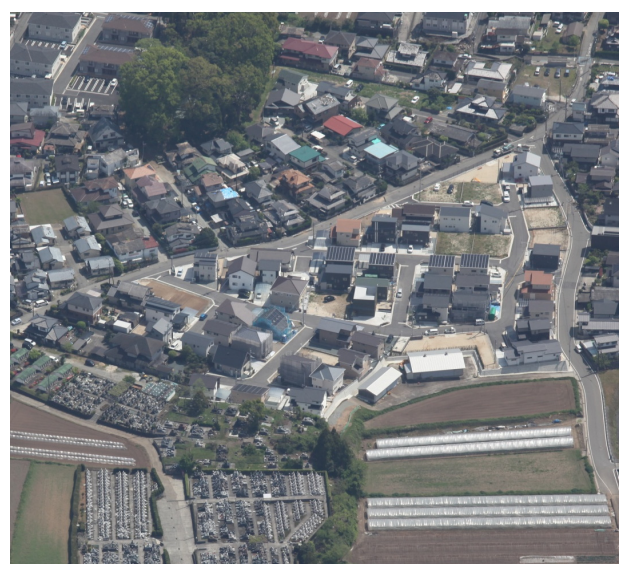

写真3 2016年4月15日撮影の空中写真 ${ }^{11}$

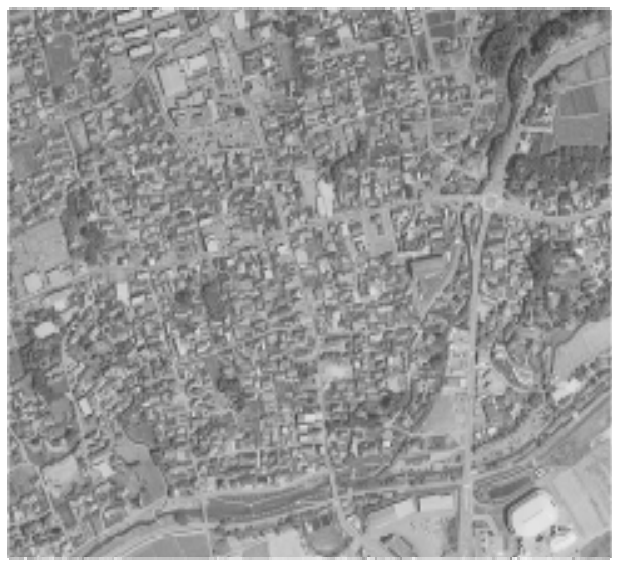

写真2 2003年撮影の空中写真 ${ }^{13)}$

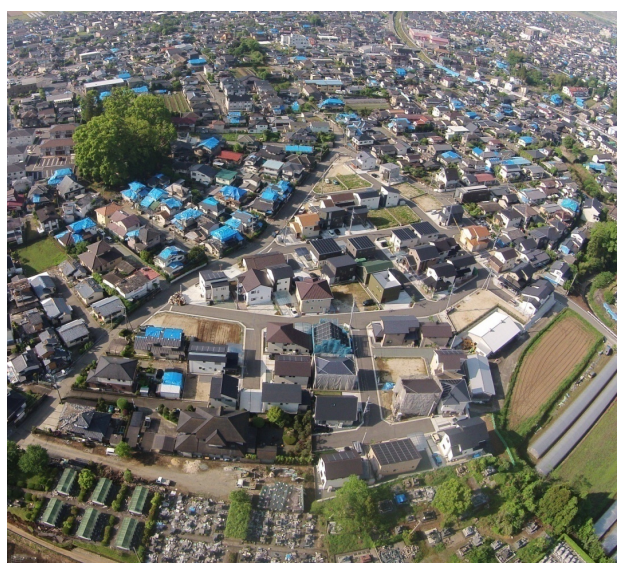

写真4 2016年4月29日撮影の空中写真 
物や解体された建物が含まれる可能性がある。また、前震についても同様である。写真 5 に倒壊と判定 した建物の例を、写真 6 に非倒壊と判定した建物の例を示寸。

空中写真による建物倒壊判定について、現地調査での目視判定との比較を行うことで、倒壊判定の精 度検証を行った。精度検証を行った対象建物は、2016 年 5 月 28 日、29 日の現地調査で図 5 に示寸道路

(図中赤線) 沿いから撮影した映像で倒壊、非倒壊を確認できた安永地区の建物 159 棟とする。なお、 現地調査での目視判定は、空中写真による倒壊判定と同一の判定基準として行った。表 3 に倒壊判定の 精度検証結果を示す。安永地区の倒壊判定精度は 96.2\%であった。現地調査での目視判定で倒壊と判定 した 25 棟のうち、6 棟は空中写真による倒壊判定で非倒壊と判定していた。つまり、倒壊建物を約 $25 \%$ 少なく評価していた。ただし、現地調査での目視判定で倒壊と判定した建物には、倒壊判定に用いた空 中写真の撮影日である 4 月 29 日から、5 月 28 日、29 日の現地調查までの間に倒壊および解体した建物 が含まれている可能性がある。また、空中写真より倒壊した建物を判定できなった理由としては、ドロ ーンによる空撮は人口集中地区外で行ったため、大きな建物による障害や映像の不鮮明さ等で見えにく い範囲があったことや、 1 層が崩壊しているが 2 層が倒壊していない建物を非倒壊建物と判断したこと が挙げられる。なお、上記の理由より、空中写真からは倒壊判定が不可能であった建物を含む図 5 に示 寸道路 (図中青線) 沿いに立地する 255 棟に対して、現地調査による倒壊判定を行った。以降の図では、 図 5 に示寸道路沿いに立地する建物に対して、現地調査による倒壊判定結果を反映し、本震後の倒壊判 定精度を向上させている。

図 6 に上記の手順で作成した対象範囲の建築年の分布を示寸。同図より、対象範囲の北側に比較的新 しい建物が多いことが分かる。図 7 に熊本地震による倒壊建物の分布を示寸。前震により倒壊した建物 は、県道 28 号線と秋津川の間に集中し、東西方向に帯状に分布していることが同図より分かる。本震に より倒壊した建物は、前震により倒壊した建物と同様に東西方向に帯状に分布しているが、より北側へ 広がっている。また、対象範囲の被害は前震では西側に多いが、本震では東側にも拡大している。

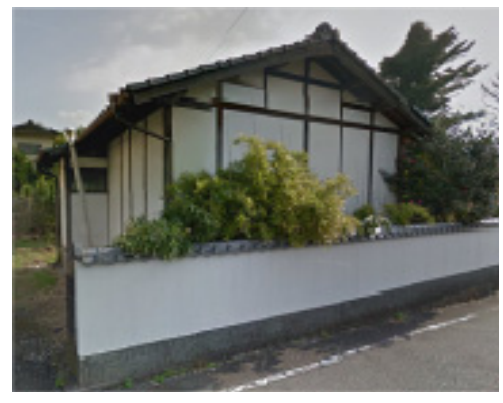

(a) Google Street View ${ }^{17}$ (2013/12 撮影)

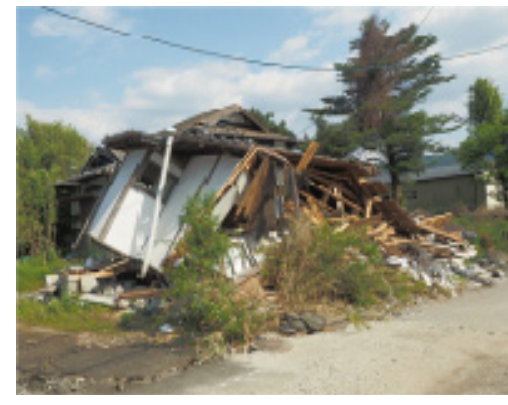

(b) 現地調査

(2016/4/29 撮影)

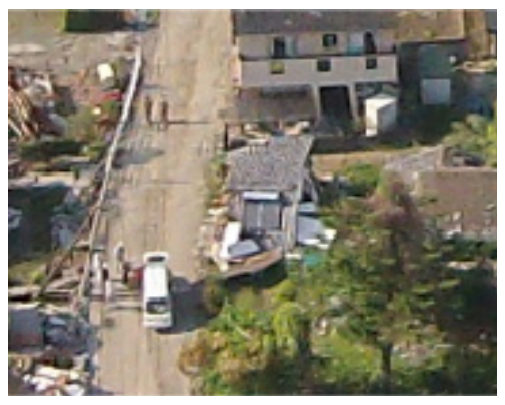

(c) 空中写真 (2016/4/29 撮影)

写真 5 倒壊と判定した建物の例

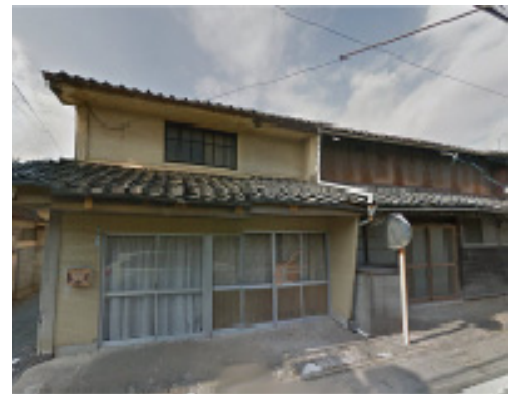

(a) Google Street View ${ }^{17)}$ (2013/12 撮影)

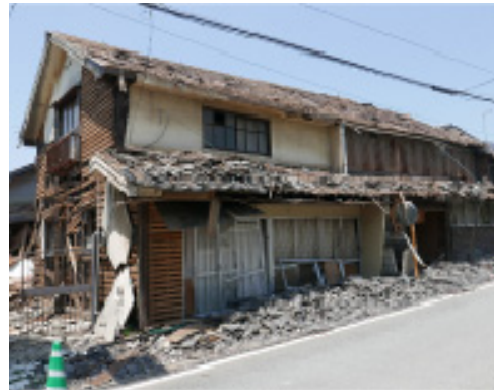

(b) 現地調查

(2016/4/30 撮影)

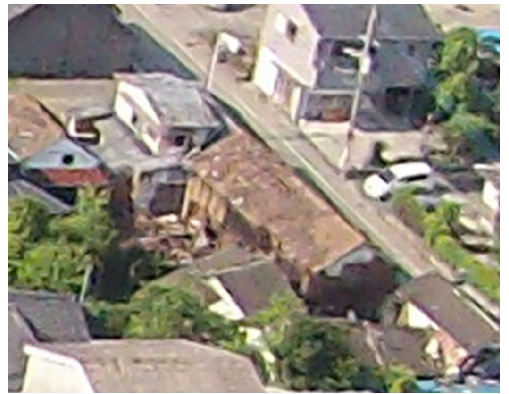

(c) 空中写真

(2016/4/29 撮影)

写真 6 非倒壊と判定した建物の例 
表3 倒壊判定の精度検証結果

\begin{tabular}{|c|c|c|c|c|}
\hline $\begin{array}{c}\text { 空中写真 } \\
\text { による判定 }\end{array}$ & $\begin{array}{c}\text { 現地調査での } \\
\text { 目視判定 }\end{array}$ & 棟数 (棟) & 割合 $(\%)$ & 検証結果 \\
\hline $\begin{array}{l}\text { 倒壊 } \\
\end{array}$ & $\begin{array}{l}\text { 倒壊 } \\
\end{array}$ & 19 & 11.9 & \multirow{2}{*}{$\begin{array}{c}\text { 正 } \\
(96.2 \%)\end{array}$} \\
\hline 非倒壊 & 非倒壊 & 134 & 84.3 & \\
\hline 倒壊 & 非倒壊 & 0 & 0.0 & \multirow{2}{*}{$\begin{array}{c}\text { 䛊 } \\
(3.8 \%)\end{array}$} \\
\hline 非倒壊 & $\begin{array}{l}\text { 倒壊 } \\
\end{array}$ & 6 & 3.8 & \\
\hline \multicolumn{2}{|c|}{ 合計 } & 159 & 100.0 & \\
\hline
\end{tabular}

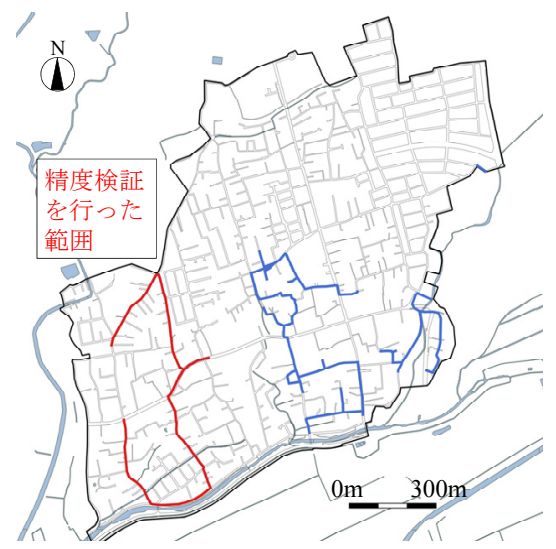

図5現地調査の際に通った道路

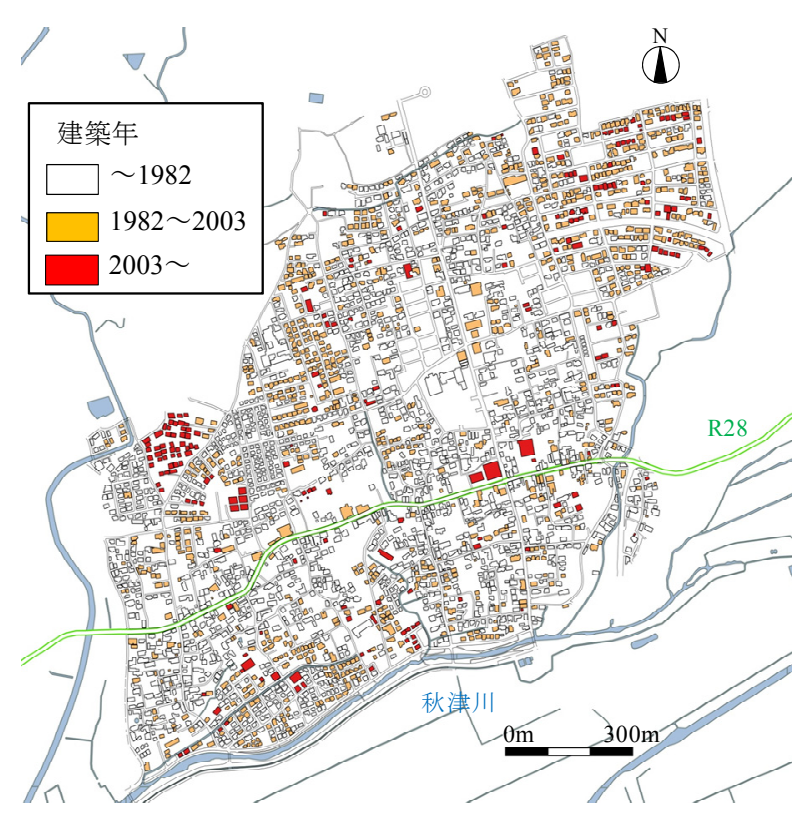

図6 建築年の分布

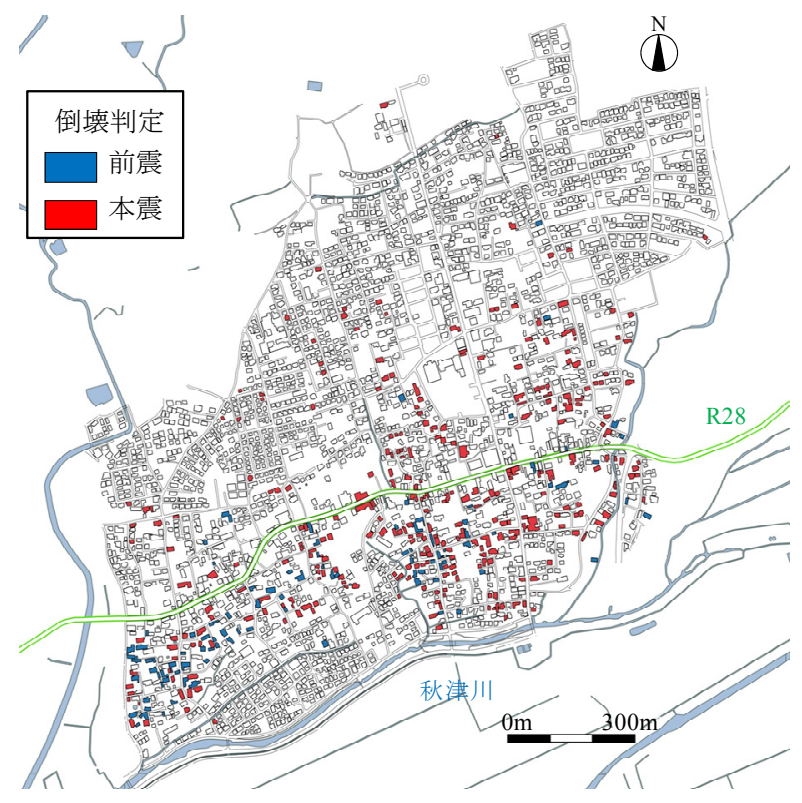

図7倒壊建物の分布

\section{4. 地盤の H/V スペクトル比と建物倒壊被害}

本章では、常時微動計測から求めた地盤の $\mathrm{H} / \mathrm{V}$ スペクトル比と倒壊建物との関係について分析を行う。 図 8、図 9 に現地で実施した地盤の常時微動計測から求めた $\mathrm{H} / \mathrm{V}$ スペクトル比を示す。常時微動計測は、 水平 2 成分、鉛直 1 成分の過減衰型加速度計を用いて、サンプリング周波数は $100 \mathrm{~Hz}$ として、7 分間行 った。計測データは 40.96 秒間で分割した後にノイズの少ない波を選定し、フーリエ変換を行い、アン サンブル平均とバンド幅 $0.1 \mathrm{~Hz}$ の Parzen Window 処理により平滑化を行った。同図の常時微動計測は加 速度計によって行われたため、低振動数での計測結果が必ずしも精度が高くなく、凡そ $1 \mathrm{~Hz}$ 以下で $\mathrm{H} / \mathrm{V}$ スペクトル比が増加している計測結果が存在する。同図では $1 \mathrm{~Hz}$ 付近の卓越を確認するために、低振動 数の結果についても掲載しているが、本論では $1 \mathrm{~Hz}$ 以上の $\mathrm{H} / \mathrm{V}$ スペクトル比について議論することに注 意されたい。

図 8 は安永地区、図 9 は宮園・木山・辻の城地区での常時微動計測結果を示している。同図において、 $1 \sim 3 \mathrm{~Hz}$ に $\mathrm{H} / \mathrm{V}$ スペクトル比の卓越が見られる。しかし、倒壊建物集中域の中でも、 $\mathrm{H} / \mathrm{V}$ スペクトル比の 
卓越振動数には差が見られることや、図 8 において倒壊建物がほとんど存在していない秋津川周辺の地 域に $1 \mathrm{~Hz}$ 付近に明瞭なピークが見られることなどから、 $\mathrm{H} / \mathrm{V}$ スペクトル比の卓越振動数やピーク值と倒 壊建物との間に明瞭な対応関係が見られないことが分かる。以上より、建物の倒壊原因を $\mathrm{H} / \mathrm{V}$ スペクト ル比の卓越振動数より推察することは難しい。

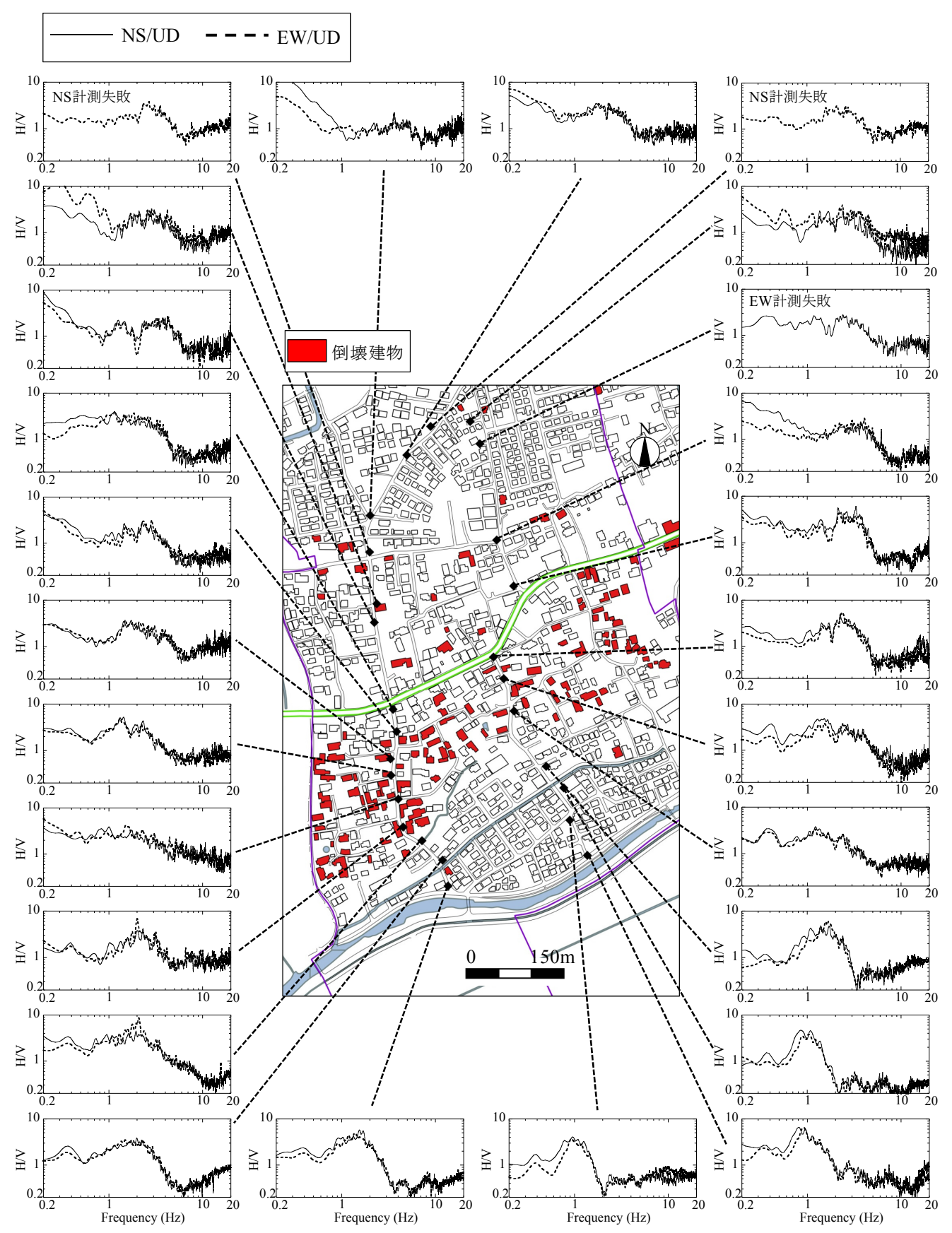

図8 安永での常時微動計測結果 


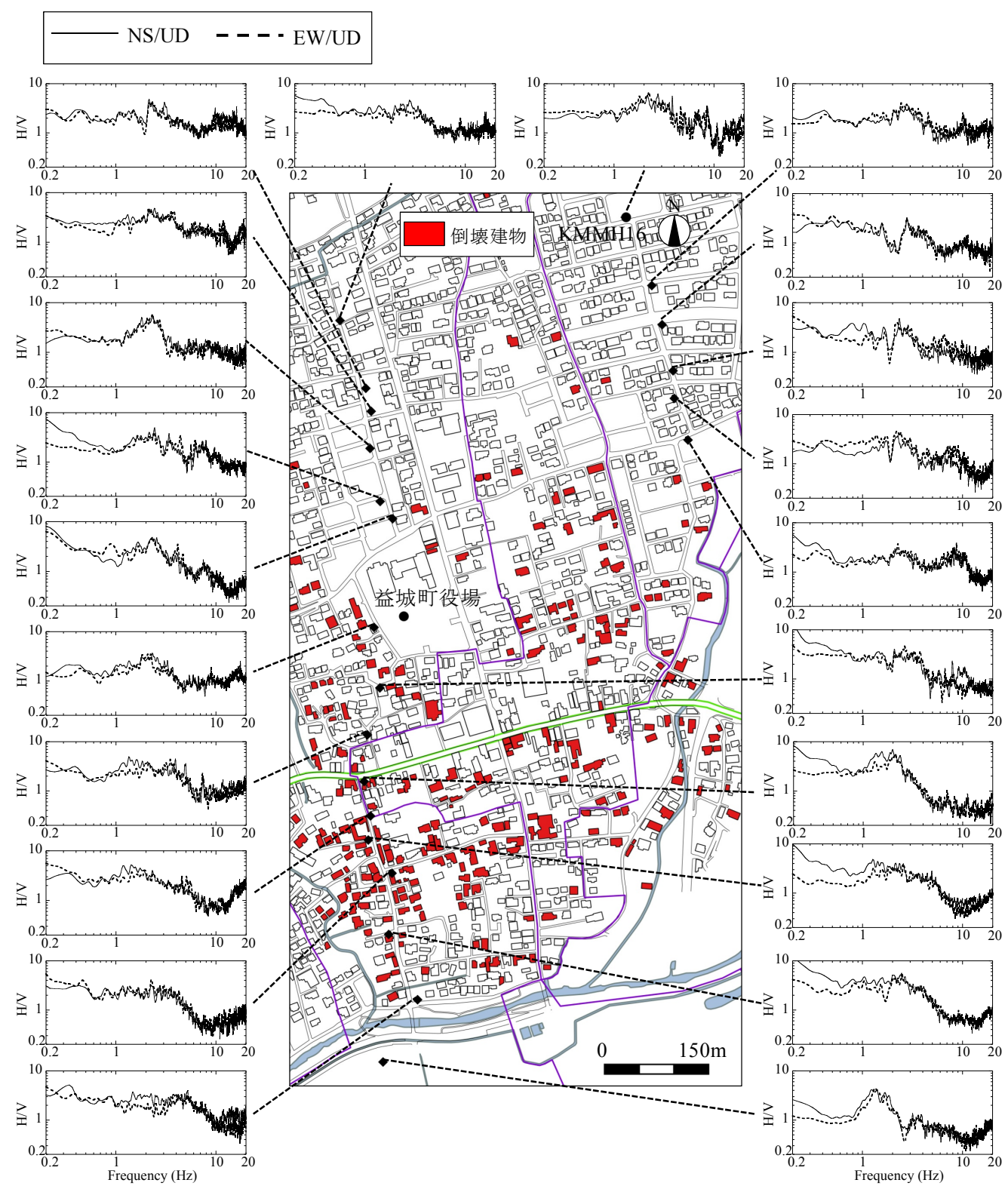

図 9 宮園・木山・辻の城での常時微動計測結果

上記の常時微動計測に加え、前震・本震時に震度計が設置されていた益城町役場の建物基礎および周 辺の地盤の常時微動計測を行った結果を図 10 に示寸。益城町役場の震度計は建物内に設置されていたこ とをふまえて、図 10(d)に示すように、益城町役場の建物基礎の上(計測点(1))および住宅が建ち並ぶ役場 の盛土の下(計測点(2))で同時計測を実施した。なお、計測および処理方法は上記の常時微動計測と同様 である。図 10(a)，(b)には、計測点(1)、(2)の H/V スペクトル比を示す。同図より、計測点(1)、(2)ともに 2.0 2.5 Hz 付近で $\mathrm{H} / \mathrm{V}$ スペクトル比の卓越が見られるが、計測点(2)に比べて計測点(1)のほうが卓越が大 きいことが分かる。図10(c)には、計測点(1)で得られたフーリエスペクトルを計測点(2)のフーリエスペク トルで除したフーリエスペクトル比を示す。同図より、計測点(1)の常時微動の水平動振幅は、計測点(2) に比べて 2 3Hz 付近で 2 3 倍程度大きいことが確認できる。計測点(1)、(2)の H/V スペクトル比の振幅が 異なるため、益城町役場の震度計の観測記録が周辺地盤の摇れと異なっていた可能性がある。また、被 害の解釈に益城町役場の震度計の記録を用いることが適切か検討の余地がある。 


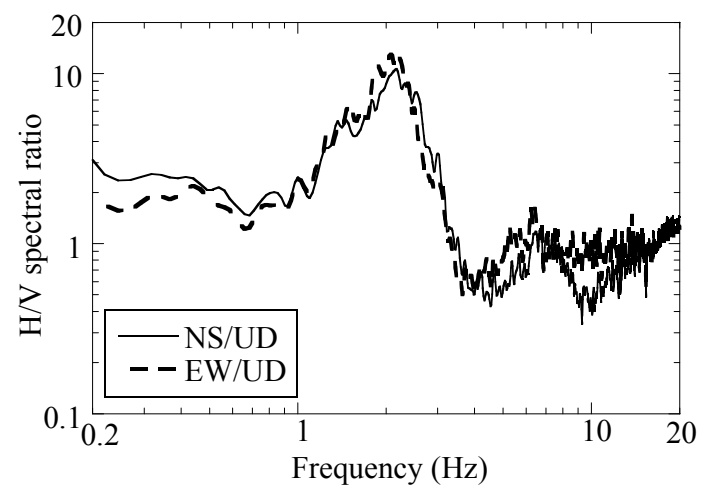

(a) 計測点(1)での $\mathrm{H} / \mathrm{V}$ スペクトル比

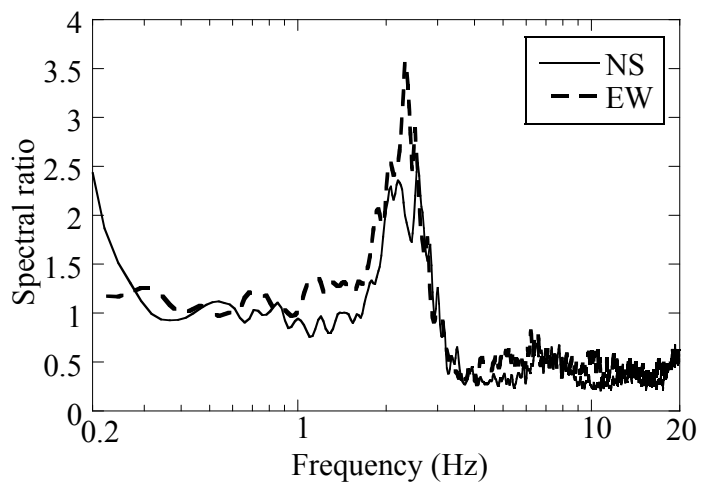

(c) フーリエスペクトル比

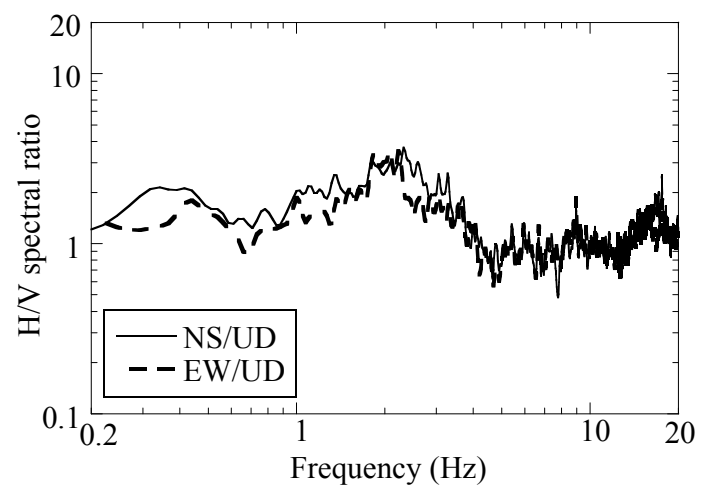

(b) 計測点(2)での $\mathrm{H} / \mathrm{V}$ スペクトル比

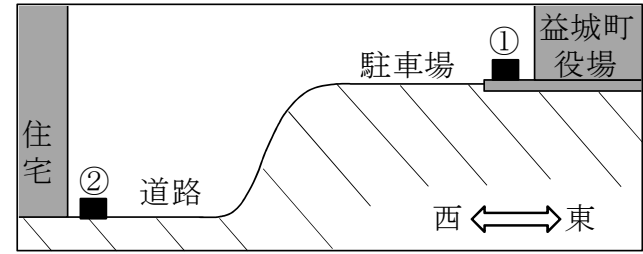

(d) 計測位置

図 10 益城町役場での常時微動計測結果

\section{5. 倒壊率の分析}

\section{1 倒壊率の算定方法}

本章では各地域の倒壊率を分析するために、図11に示すようなゾーン区分を行う。ゾーン区分は、大 字境界、東西方向の道路、標高線を参考に、各ゾーンの対象建物が 100 棟程度以内におさまるように 37 のゾーンに区分した。図中の数字はゾーン区分内の対象建物棟数を表す。図12にゾーン区分毎の築1982 年以降の割合を示す。同図より、築1982年以降の建物の割合は、県道28号付近では低く、対象範囲の北 部では高いことが分かる。

本論では、前震および本震での倒壊率や、建築年と倒壊率との関係を分析するために、倒壊率、前震 倒壊率、築 1982 年以前倒壊率、築 1982 年以降倒壊率を下記のように各ゾーンごとに算出する。

[倒壊率 $](\%)=[$ 前震および本震での倒壞建物棟数 $]$ / [全建物棟数 $] \times 100$

[前震倒壊率 $](\%)=[$ 前震での倒壊建物棟数 $] /$ [全建物棟数 $] \times 100$

[築 1982 年以前倒壊率] $(\%)=$ [築 1982 年以前の倒壊建物棟数] / [築 1982 年以前の建物棟数 $] \times 100$

[築 1982 年以降倒壊率 $](\%)=$ [築 1982 年以降の倒壊建物棟数] / [築 1982 年以降の建物棟数 $] \times 100$

以降の「倒壊率」は、建築年に関わらずゾーン内の全建物を対象とした本震後の倒壊率であることに注 意されたい。 


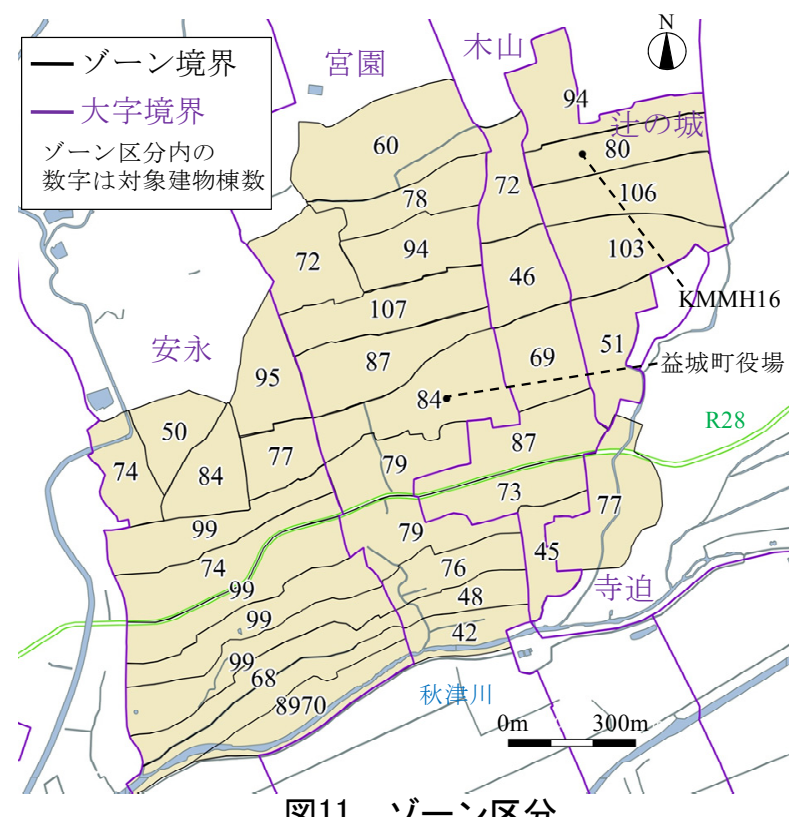

図11 ゾーン区分

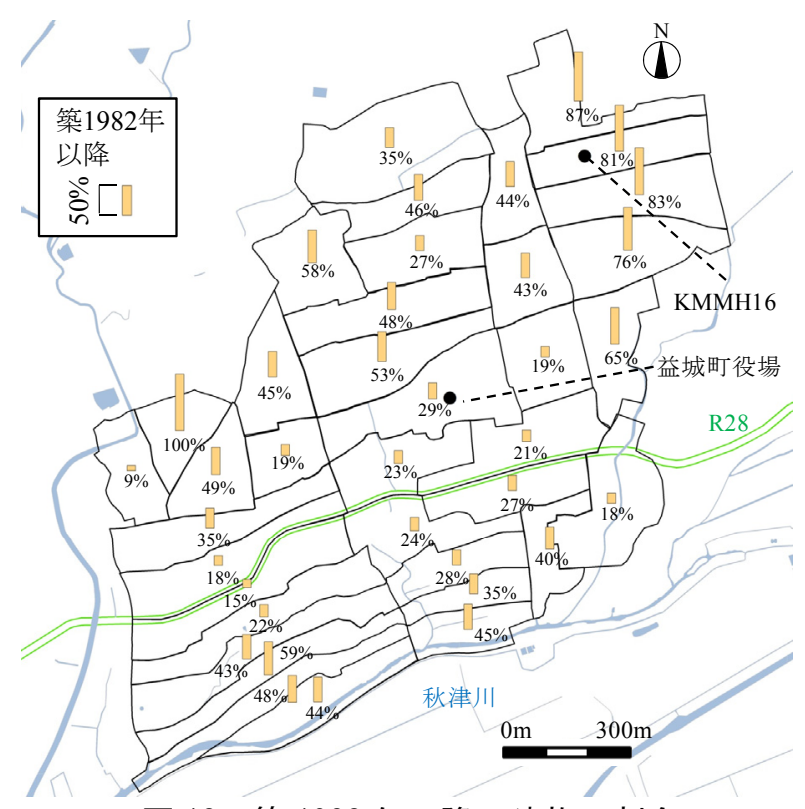

図 12 築 1982 年以降の建物の割合

\section{2 前震 $\cdot$ 本震、建築年との関係}

図 13 に築 1982 年以前倒壊率および築 1982 年以降倒壊率をゾーン区分毎に示す。図 13(a)では築 1982 年以前の倒壞建物棟数に対する、前震および本震での倒壊建物棟数の比を色分けして示している。図 13(b)の築 1982 年以降の倒壊建物棟数についても同様に色分けしている。なお、棒グラフの表示がない ゾーンは、倒壊建物がなかったことを意味しており、築 1982 年以前の建物が存在しなかったゾーンには 斜線を引いている。同図の(a), (b)を比較すると築 1982 年以降倒壊率に比べて、築 1982 年以前倒壊率が 大きいゾーンが多いことが分かる。

図 14 では、前震およびお本震での倒壊判定や建築年と倒壊建物との関係を分析する。図 14(a)には、図 14(b), (c)で着目しているゾーンA，B の位置を示している。図 14(b)では、倒壊率と前震倒壊率との関係 を示す。図 14(c)では、築 1982 年以前倒壊率と築 1982 年以降倒壊率との関係を示す。ただし図 14(c)で は、全ゾーンのうち築 1982 年以前および以降の建物棟数が 20 棟以上となる 20 ゾーンのみを対象として いる。図 14(b)より、ゾーン A, B では倒壊率が $60 \%$ を超えており甚大な被害を被ったことが分かる。そ のうち、ゾーン A では前震で倒壊した棟数が本震で倒壊した棟数を上回っており、前震による被害が大 きかったことが分かる。他にも、前震倒壊率が 10\%を超えるゾーンが存在することを確認できる。図 14(c) より、築 1982 年以降倒壊率が $10 \%$ 程度であるゾーンが複数存在し、築 1982 年以降の倒壊建物も少なく ないことが確認できる。特にゾーン B では 1981 年の新耐震設計法施行後に建てられた築 1982 年以降の 建物でも、60\%程度が倒壊しており、築 1982 年以前倒壊率と築 1982 年以降倒壊率で顕著な差が見られ ない。その上、2000 年の建築基準法改正以降に建てられた築 2003 年以降の建物も数棟ではあるものの 倒壊していた。 


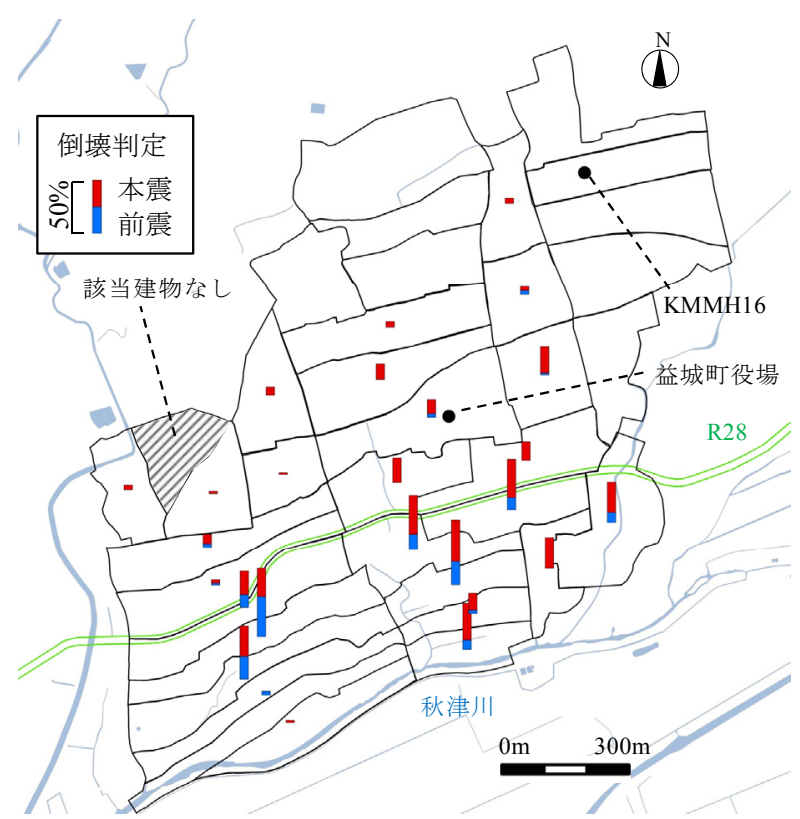

(a) 築 1982 年以前倒壊率

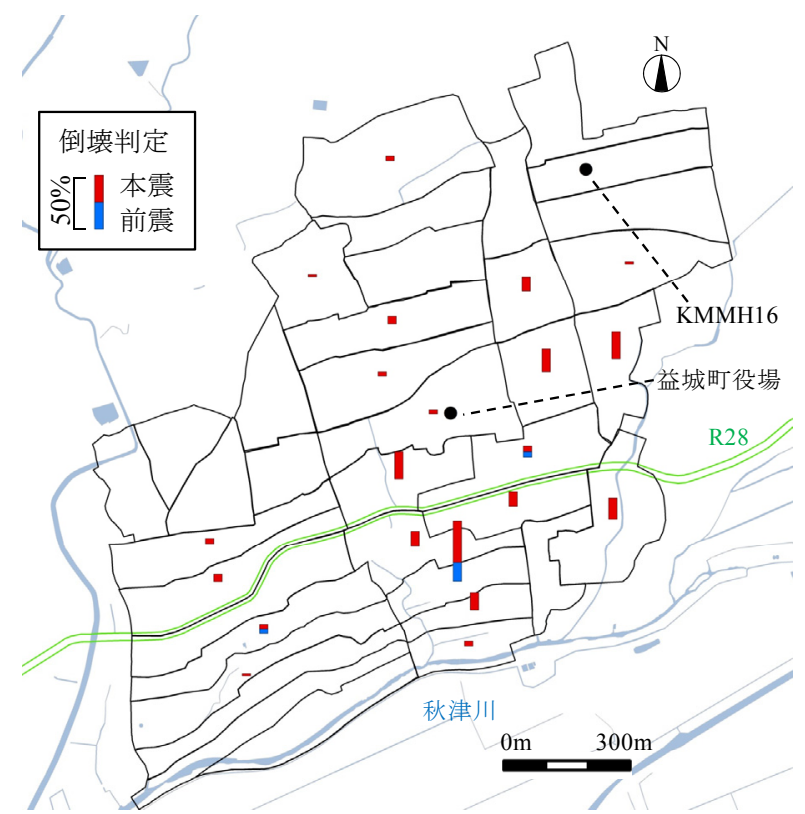

(b) 築 1982 年以降倒壊率

図 13 築 1982 年以前倒壊率および築 1982 年以降倒壊率

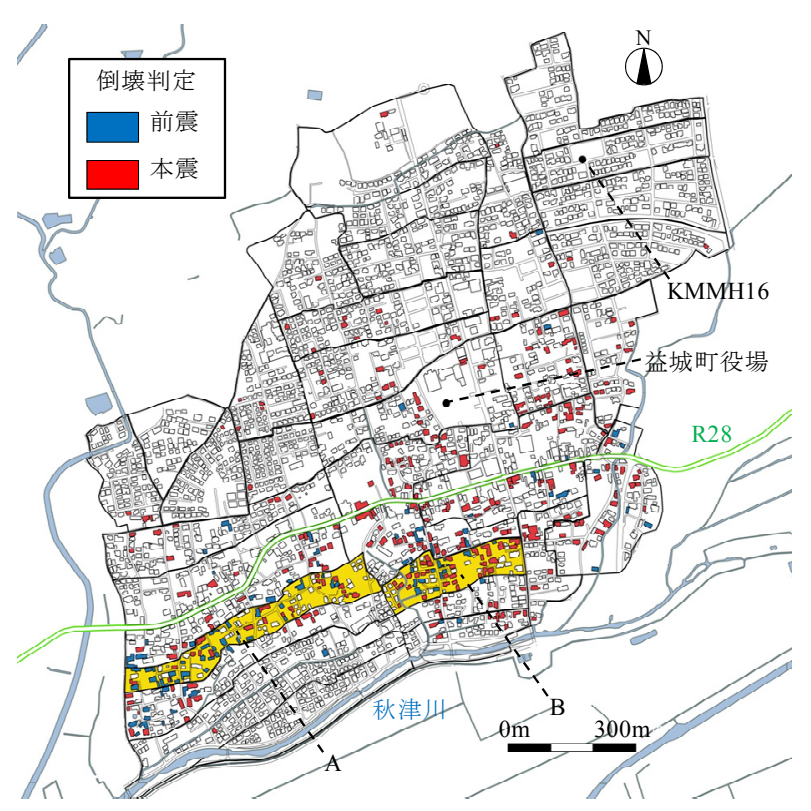

(a) ゾーン A, B の位置

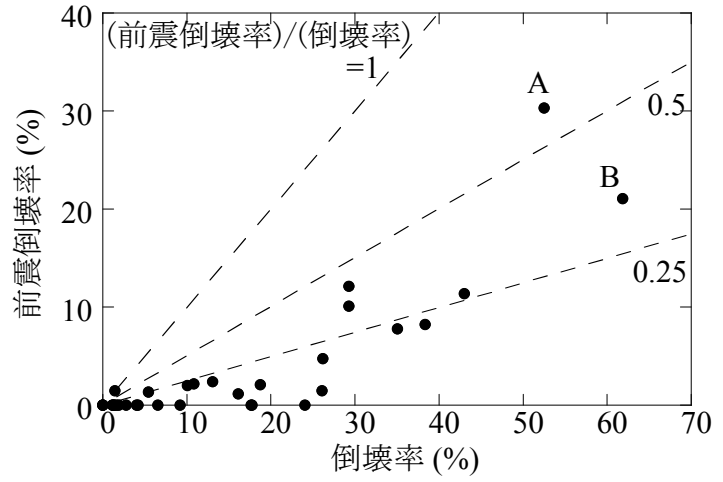

(b) 倒壊率と前震倒壊率との関係

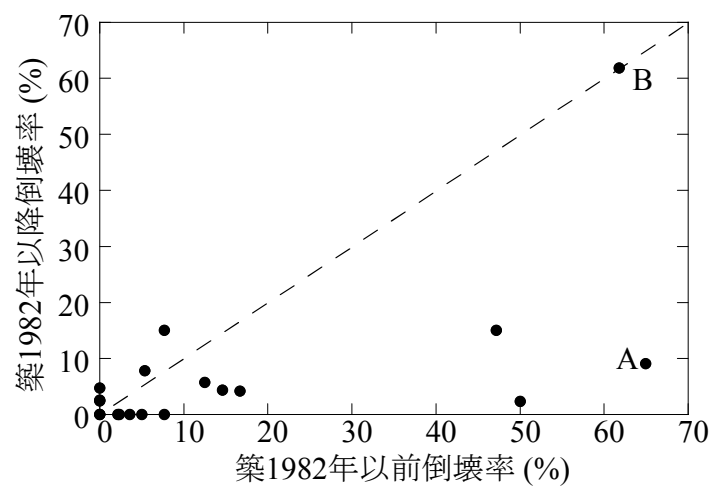

(c) 築 1982 年以前倒壊率と

築 1982 年以降倒壊率との関係

図 14 前震 - 本震での倒壊率および建築年と倒壊率との関係 


\section{3 耐震化率との関係}

本節では、益城町建築物耐震改修促進計画 2)（以下、益城町耐促計画）に基づいて、益城町の耐震化 率と倒壞建物との関係について考察する。図 15 では、大字別の本論で求めた建築年ごとの建物の割合と 益城町耐促計画による 2011 年 1 月の戸建て住宅の耐震化率を比較して示寸。本論の建築年は、築 1982 年以前、築 1982 年〜2003 年、築 2003 年以降の 3 つに分けて示している。一方、益城町耐促計画による 戸建て住宅の耐震化率は、対象住宅のうち「而震性を有する建築物」の割合である。「而震性を有する建 築物」は、築 1982 年以降の建物に加えて、築 1981 年以前の建物の中で、耐震診断等によって耐震性を 満たしていると確認された建物および而震改修・建て替えにより耐震化した建物である ${ }^{2,3)}$ 。築 1982 年 以降の建物を「耐震性を有する建築物」と寸る理由は、1995 年兵庫県南部地震の際に、新耐震設計法施 行前の築 1981 年以前の建物に大きな被害が生じた ${ }^{18)}$ とされているためである ${ }^{3)}$ 。なお、図 15 では、「耐 震性を有する建築物」以外の建物を文献 2) と同様に「耐震性が不十分な建築物」と表記している。

はじめに、益城町の耐震化率について確認する。2011 年度における益城町全体の戸建て住宅の耐震化 率は、図 15 に示寸安永、宮園、木山、寺迫と同程度の $63.3 \%$ 2)であった。一方、国は 2025 年度末まで に住宅の耐震化率を $95 \%{ }^{3}{ }^{3}$ にすることを目標としている。以上より、2011 年度の益城町の耐震化率と国 の目標には差があった。

本論で求めた築 1982 年以降の建物の割合と益城町耐促計画における而震化率との関係について確認 するために、まず、図 15 に示す本論と益城町耐促計画の対象棟数を比較する。地区の南西部分の一部分 のみを対象としている寺迫を除くと、最大で $15 \%$ 程度の差はあるものの各大字の対象棟数が概ね対応し ていることが分かる。棟数が異なる理由として、本論では大字の全域を対象範囲としていないこと、本 論の対象建物は 3 章に示すように普通建物 ${ }^{10}$ が主であるのに対し、益城町耐促計画は戸建て住宅が対象 であること、本論では築 1982 年以前の建物を 1982 年以降に建て替えた場合、築 1982 年以降の建物とし て計上できていない可能性があること、本論は 2016 年の調查時の建物棟数であるのに対し、益城町而促 計画は 2011 年時点での建物棟数であること等が考えられる。次に、築 1982 年以降の建物の割合と耐震 化率を比較すると、安永、宮園、木山の耐震化率は、築 1982 年以降の建物の割合に比べてどの地区も約 20\%程度高い。その理由は上記のほかに、「而震性を有する建築物」は築 1982 年以降の建物に加えて築 1982 年以前の耐震補強等を行った建物を含むためであると考えられる。なお、2000 年の建築基準法改正 以降に建てられた築 2003 年以降の建物はどの大字でも 1 割未満と多くはなかった。

以上の検討より、本論で求めた築 1982 年以降の建物の割合と耐震化率には対応関係があるため、以降 の検討では建築年と倒壊建物との関係を考察する。図 16 には大字別の築 1982 年以前倒壊率と築 1982 年以降倒壊率を示す。同図より、全ての大字で築 1982 年以前倒壊率のほうが築 1982 年以降倒壊率を上 回るものの、宮園や木山の築 1982 年以降倒壊率についても約 $10 \%$ と決して低くないことが分かる。ま た、前節で示したように倒壊被害の多いジーンでは築 1982 年以前倒壊率と築 1982 年以降倒壊率に殆ど 差がなく $60 \%$ を超えていた。これは、兵庫県南部地震時に新而震設計法で設計された建物は被害が少な く、耐震補強の必要性が低いとされた $\left.{ }^{3}, 18\right)$ こと異なり、熊本地震のように建築基準法の規定を大きく 上回る地震動を受けた場合は、築 1982 年以降の建物であっても決して安全とは言い難い。また、築 1982 年の建物であっても 2016 年時点で建築後 30 年以上を経ており、生物劣化による而震性能の低下も懸念 される。以上より、強い地震動が予測される地域において、築 1982 年以降の建物の耐震性能の向上も必 要となると考えられる。 


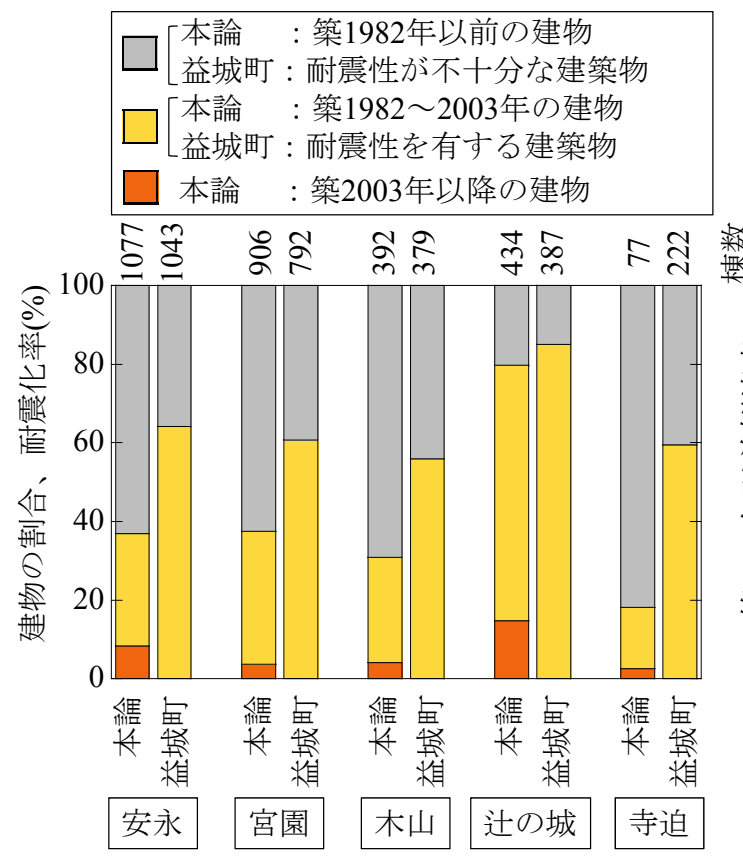

図 15 大字別の建築年ごとの 建物の割合

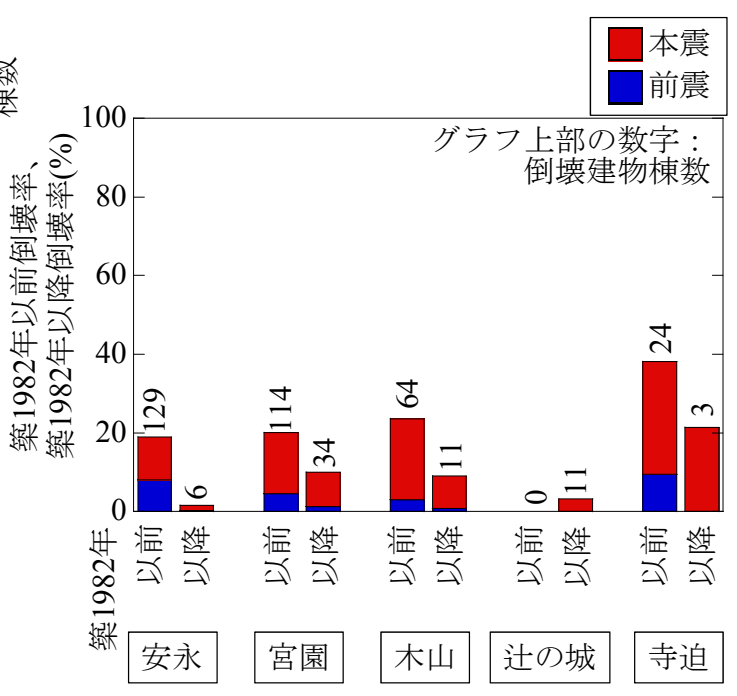

図 16 大字別の築 1982 年以前倒壊率 と築 1982 年以降倒壊率

\section{6. まとめ}

本論では、2016 年熊本地震で建物被害が甚大であった益城町（安永・宮園・木山・辻の城・寺迫地区） の主に木造建物を対象に、空中写真によって建築年と倒壊の判定を行った。本震での倒壊判定に用いた ドローンによる空中写真は、人口集中地区外から筆者らが撮影したため、大きな建物による障害や、映 像の不鮮明さ等が原因となり、現地調査での目視判定に比べて倒壊建物を約 $25 \%$ 少なく評価していたこ とを確認した。

分析の結果、明らかとなった被害傾向を以下に列挙する。

1) 益城町では帯状の倒壊被害集中域が見られたが、前震および本震による倒壊被害集中域にずれがあ った。また、常時微動計測から求めた地盤の $\mathrm{H} / \mathrm{V}$ スペクトル比の卓越振動数やピーク值と倒壊建物 との間には明瞭な対応関係は見られなかった。なお、前震だけで倒壊した建物も存在しており、本 震よりも前震による倒壊棟数が多い地域も存在した。

2) 築 1982 年以降の建物に比べて築 1982 年以前の建物の倒壊被害が多かった。しかし、1981 年の新耐 震設計法施行後に設計された建物でも、 $60 \%$ 近くが倒壊した地域があった。これは、兵庫県南部地 震時に新耐震設計法で設計された建物は被害が少なく、耐震補強の必要性が低いとされた と異なる。しかも、同地域では、築 1982 年以前と築 1982 年以降の倒壊率にはほとんど差が無い。

国は、2025年度末までに住宅の耐震化率を95\%にすることを目標として掲げている。而震化された住 宅には、耐震補強済の住宅に加えて新耐震設計法施行後の築1981年以降の住宅が含まれるが、益城町の 倒壊被害集中域では半数程度が倒壊を免れなかった。建築基準法改正後の2000年以降に建てられた住宅 も被害が確認されている。また、築1982年の建物であっても2016年時点で建築後30年以上を経ており、 生物劣化による耐震性能の低下も懸念される。今後、強い地震動が予測される地域においては、人口密 集度や社会的な影響度等も鑑みて、築1982年以降の建物の耐震性能の向上も必要となると考えられる。 


\section{謝 辞}

本論の作成にあたっては、国立研究開発法人防災科学技術研究所による強震観測網および気象庁、熊 本県によって公開されている観測記録を使用させて頂いた。また、国土交通省およびアジア航測株式会 社の空中写真、地理情報を使用させて頂いた。京都大学大学院・南部恭広氏には現地調查でご協力を得 た。記して御礼申し上げる。

\section{参考文献}

1) 気象庁:「平成28年(2016年)熊本地震」について(第40報)、 http://www.jma.go.jp/jma/press/1606/13a/201606130015.html（参照2016年7月6日).

2) 益城町役場 都市計画課 : 益城町建築物耐震改修促進計画、2016年3月.

3）国土交通省 : 住宅・建築物の耐震化について、 http://www.mlit.go.jp/jutakukentiku/house/jutakukentiku_house_fr_000043.html (参照2016年10月1日).

4）国土交通省国土政策局国土情報課：国土数值情報 ダウンロードサービス、 http://nlftp.mlit.go.jp/ksj/index.html（参照2016年7月4日)．

5) 政府統計の総合空口(e-stat)、http://www.e-stat.go.jp/SG1/estat/eStatTopPortal.do (参照2016年7月4日).

6) 中田高、今泉俊文 : 活断層詳細デジタルマップ、東京大学出版会、2002年 (製品シリアル番号： DAFM1240) .

7) 気象庁 : 発震機構解（精查後）、http://www.data.jma.go.jp/svd/eqev/data/mech/index.html (参照2016年7月4日).

8）国立研究開発法人防災科学技術研究所 : 強震観測網、http://www.kyoshin.bosai.go.jp/kyoshin/ (参照2016年7月4日).

9) 気象庁 : 観測記録、http://www.jma.go.jp/jma/menu/menuflash.html （参照2016年7月4日).

10)国土地理院: 基盤地図情報、基本項目、http://fgd.gsi.go.jp/download/kibansel.php (参照2016年7月4日).

11)国土地理院：地理院地図、http://mapps.gsi.go.jp/maplibSearch.do\#1（参照2016年7月4日).

12)アジア航測株式会社 : http://www.ajiko.co.jp/ (参照2016年7月4日).

13)国土地理院 : 空中写真、http://maps.gsi.go.jp (参照2016年7月4日).

14)長谷川弘忠、山崎文雄、松岡昌志 : 空撮ハイビジョン映像を用いた兵庫県南部地震による建物被害の 目視判読、土木学会論文集、No.682/I-56、pp.257-265、2001年7月.

15)震災復興都市づくり特別委員会: 阪神・淡路大震災被害実態緊急調査 被災度別建物分布状況図集(説 明書)、1995年.

16)国土地理院 : 現地の被害状況（空中写真での被災前後の比較「益城町中心部付近」）、 http://www.gsi.go.jp/BOUSAI/H27-kumamoto-earthquake-index.html\#2（参照2016年7月4日).

17)Googleマップ : https://www.google.co.jp/maps/ (参照2016年7月10日).

18) 建設省 建築震災調査委員会：平成7年阪神・淡路大震災建築震災調查委員会中間報告、1995年.

(受理 : 2016年7月21日)

（掲載決定：2016年10月19日）

（一部訂正 : 2017年10月23日）*

* 著者の責によらない事由による（理事会承認済み） 


\title{
Analyses of Building Damages in Mashiki Town
}

\section{in the 2016 Kumamoto Earthquake}

\author{
SUGINO Mina ${ }^{1)}$, YAMAMURO Ryohei ${ }^{2)}$, KOBAYASHI Sunao ${ }^{3)}$, \\ MURASE Shiori ${ }^{4)}$, OHMURA Saki ${ }^{5)}$ and HAYASHI Yasuhiro ${ }^{6)}$ \\ 1) Member, Assistant Professor, Kyoto University, Dr. Eng. \\ 2) Student Member, Graduate Student, Kyoto University \\ 3) Graduate Student, Kyoto University, Research Fellow DC1, JSPS, M. Eng. \\ 4) Undergraduate Student, Kyoto University \\ 5) Student Member, Graduate Student, Kyoto University \\ 6) Member, Professor, Kyoto University, Dr. Eng.
}

\begin{abstract}
To analyze why a lot of buildings collapsed in Mashiki town by the 2016 Kumamoto earthquake, we compared the distribution of collapsed buildings with the construction years and the result of microtremor measurements of the ground. The collapsed buildings and the construction years were judged from some aerial photographs. This study reveals that the damaged area shapes like a band, and the band caused by the foreshock is different from the band caused by the main shock. The severest area includes many collapsed wooden buildings built after Order for Enforcement of the Building Standard Act amended in 1981. In the same area, the ratios of the collapsed buildings built before 1982 and after 1982 are almost same.
\end{abstract}

Keywords : the 2016 Kumamoto Earthquake, Building Damage, Distribution of Building Damage, Construction Years, Aerial Photograph, GIS 